\title{
Newborn Head Trauma and Nursing Approach
}

\author{
Şadiye Dur* \\ Faculty of Health Sciences, Bahcesehir University, Turkey
}

*Corresponding author: Şadiye Dur, Nursing Department, Faculty of Health Sciences, Bahcesehir University, Abbasağa Mah. Ihlamur Yıldız Ca, Beşiktaş/Istanbul, Turkey.

To Cite This Article: Şadiye Dur. Newborn Head Trauma and Nursing Approach. 2020 - 9(1). AJBSR.MS.ID.001346. DOI: 10.34297/ AJBSR.2020.09.001346.

Received: 監 May 21, 2020; Published: 眥 May 28, 2020

\begin{abstract}
Trauma ranks first among the causes of child deaths. Head trauma is an important health problem in childhood and the most common cause of mortality and morbidity in that period. It's more common in infants, adolescents and boys. Weak head control in children and a larger head than the body increases the risk of head trauma. Therefore, nurses should be actively involved and take appropriate actions in protection of children from head injuries and post-trauma nursing care. Child abuse, especially shaken baby syndrome, is the leading cause of head trauma in children under one year of age. This review addresses the nursing care plan of pediatric patients suffering from head injury.
\end{abstract}

Keywords: Head Trauma; Newborn; Nurse; Nursing Care

\section{Introduction}

Traumas are one of the most important health problems of childhood and the most common cause of child deaths between 1-15 years of age. Head trauma appears to be the most common cause of death and permanent disability in childhood [1]. Approximately 200000 children per year are hospitalized due to head trauma and 4000 children die within a few hours after trauma [2]. While trauma constitutes $15 \%$ of adult deaths, this rate approaches $50 \%$ in childhood [3].

As from birth, people might suffer from any type of head injuries at any age. The application of forceps during birth, falls from the cradle or lap, traffic, occupational, home and sports accidents that occur with increasing age are the causes of head trauma [4,5]. Abusive Head Trauma (AHT), formerly known as Shaken Baby Syndrome, is the primary cause of death and the most common cause of chronic disability and permanent damage among abused infants and children [6,7]. It is also the leading cause of traumatic death and injury in children under 1 year of age [8]. The annual incidence of AHT in the first year of life ranges from 29 to 39 cases per 100,000 infants, but the actual number is probably not reported [9]. Excessive crying of an infant can make tired and sleepless parents helpless and angry in the postpartum period. When this feeling cannot be controlled, shaking the infant by the arms or trunk may lead to AHT presentation. Therefore, the person taking care of the infant needs to realize the level of stress and learn how to deal with stress. AHT can be prevented by increasing awareness through education especially in early postpartum period $[10,11]$. In the U.S., 1,000 to 1,500 AHT cases occur annually, and 30\% of these cases result in victim death [6]. The vast majority of survivors suffer from life-altering neurological disorders, including learning disabilities, visual impairment, total blindness, speech and hearing loss, seizures, autism, cerebral palsy and permanent vegetative conditions $[6,8,12,13]$.

The frequency of head injuries has not been determined clearly both in Turkey and worldwide. In the USA, it is reported that head trauma results in approximately 2500 deaths, 37,000 hospitalizations and 435,000 emergency department visits in children $[14,15]$. Every year 2000-3000 people present to hospitals due to head trauma in the UK [16]. In the study of Mirzai et al., 0-10 age group children rank first in the age distribution of reasons other than traffic accidents (32\%) [17].

\section{Various Features of Newborn Head Trauma}

\section{Anatomical Features}

a) Calvarium (skull) is soft in children, especially in newborns and they are affected more by head trauma. Collapse fractures are more common in this group [18]. 
b) Subarachnoid space is narrowed and therefore they lack the buffering mechanism of the subarachnoid space against the force of trauma $[1,18]$.

c) The head is larger than the body, and the rate of head trauma is high in general types of trauma $[1,18]$.

\section{Physiological Properties}

a) While the water content of the brain is $88-90 \%$ in newborns, it is around $75-77 \%$ in adults. Therefore, newborns are more affected by acceleration-deceleration type trauma $[18,19]$.

b) Newborn skull is more ligamentous than adult skull [1, 19].

c) A child's brain has a lower degree of myelination, making it more prone to diffuse axonal injury (DAI) [18].

d) Resistance to hypertension and hypoxia is lower and the risk of secondary brain injury is high [20].

e) Patients with open fontanelle and sutures better tolerate increased intracranial pressure [19].

f) Subcutaneous adipose tissue is at its highest level, especially around 9 months. Therefore, it is very difficult to find peripheral vascular access in small children [20].

\section{Nursing Care of Pediatric Patients with Head Trauma}

Today, the purpose of nursing care is to prevent secondary brain tissue damage, since there is no specific treatment method for brain tissue damaged by trauma [21]. The roles of nurses in caring for a patient suffering from head trauma focus on prevention of head trauma and acute interventions [22,23].

Nursing care starts at the time of meeting the child for the first time, usually in the emergency department, the unit where s/ he first presents. In primary and secondary diagnoses of a child, a clear airway, respiration and circulation should be assessed at first. Primary evaluation and first interventions in head injury $[19,20]$ :

a. It's ensured that the airway is clear and the spine is stabilized.

b. Respiratory pattern and adequacy are evaluated and high flow oxygen is given by mask.

c. Circulation and bleeding are evaluated, fluid support is provided according to the findings of hypovolemia.

d. Using the Glasgow coma scale, the level of consciousness and pupil size, symmetry and response to light are evaluated (Swift neurological examination).

e. Blood glucose level is monitored and treated [18-20].
The nursing diagnosis of a child with a head trauma is made by considering the clinical, laboratory, and family history findings of the child and the care is planned taking into consideration the priority order of the problem $[20,23]$.

\section{CSF Drainage and External Ventricular Drainage System}

Discharge of CSF using external ventricular drainage and reducing intracranial pressure reduce the volume of fluid in the skull. Proper monitoring of external ventricular drainage is vital to prevent complications [15,18].

\section{Nursing Interventions and Intracranial Pressure}

Intracranial pressure monitoring provides objective data required for patient care. Findings related to paralysis, bleeding and increased intracranial pressure should be monitored. Environmental and painful stimuli should be reduced. Normal $\mathrm{PaO}_{2}$, $\mathrm{pCO}_{2}$ should be maintained, airway aspiration should be performed carefully and normal body temperature should be maintained $[20,23,24]$.

\section{Patient's Position}

To reduce venous pressure, the head should be kept 20-30 degrees high, midline. Turning the head can block the blood flow of the jugular vein and increase intracranial pressure. The head should not be turned suddenly. During intubation, maneuvers of bending the head or raising the chin should be avoided [15,20,25].

\section{Sedation and Analgesia}

Sedation and analgesia prevent cerebral metabolic damage, reduce cerebral blood volume and intracranial pressure. Thus, secondary damage is prevented by reducing oxygen consumption. It is the responsibility of the nurse to monitor the effect and side effects of the drugs in the patient receiving sedation and analgesia $[23,26]$.

\section{Epilepsy Prophylaxis}

It is reported that $12 \%-40 \%$ of patients with moderate to severe head trauma have epilepsy seizures within the first seven days. Newborns and young children are at higher risk for epilepsy because of very rapid brain development $[18,25,26]$.

\section{Temperature Check}

A one degree increase in high fever increases metabolic damage by $10-13 \%$ and causes cerebral vasodilation. Keeping the body temperature below 38 degrees by using antipyretics prevents neurological damage. The benefits of therapeutic hypothermia are still controversial $[18,26]$.

\section{Glucose Check}

Hyperglycemia occurs in $38 \%$ of children with head trauma and is associated with poor results in children with a blood glucose level of less than $200 \mathrm{mg} / \mathrm{dl}[15,25,26]$. 


\section{Diet}

The calorie need of a child with head trauma increases due to hypermetabolic conditions, as manifested by fever, increased oxygen consumption, tachycardia and hyperglycemia. Diet is vital for maintaining organ functions and recovery in these children. Malnutrition delays wound healing, increases the risk of infection, and delays healing. If the child is unconscious, $\mathrm{s} /$ he is fed intravenously [18,25].

\section{Conclusion and Recommendations}

Head trauma which causes high mortality and morbidity in childhood continue to exist as an important health problem in Turkey and worldwide, as it causes physiological and psychological conditions in children. Evaluation of the infant as a whole is important for the prevention of any future morbidity. It is very important for the protection of public health that the factors can be prevented by intra- and interdisciplinary education and family education. Preparing appropriate training programs will undoubtedly affect infant mortality rates and community health positively. In addition, planning and implementation of appropriate nursing interventions and patient evaluation to prevent post-trauma secondary brain tissue damage, early recognition of risk factors will reduce the risk of mortality and morbidity due to trauma.

\section{References}

1. Altınörs M, Kabataş S (2012) Çocukluk Çağı Kafa Travmaları. İç: Karaböcüoğlu M, et al. [Eds.]. Çocuk Acil Tıp, Nobel Tıp Kitapevi, Cilt 2: 2117- 2130.

2. Çavuşoğlu H (2011) Çocuk Sağlığı Hemşireliği. Cilt 2, (10 $0^{\text {th }}$ edn) Sistem Of set Ltd. Şirketi, Ankara.

3. Lorenne Newberry (2003) Sheehy's Emergency Nursing, Principles and Practice. $\left(5^{\text {th }}\right.$ edn) Mosby.

4. McNett M, Doheny M, Sedlak AC, Ludwick R. (2010) Judgments of critical care nurses about risk for secondary brain injury. American Association of Critical-Care Nurses 19(3): 250-260.

5. Yılmaz K, Koçak H, Özkardeş S, inanır İ (2011) Nursing care of the patient with pediatric head injury in the emergency room. Turkish Journal of Neurosurgery 21 (Suppl 6).

6. Gordy C, Kuns B (2013) Pediatric abusive head trauma. Nursing clinics of North America 48(2): 193-201.

7. Rideout L (2016) Nurses perceptions of barriers and facilitators affecting the shaken baby syndrome education initiative: an exploratory study of a mass achusetts public policy. Journal of Trauma Nursing 23(3): 125137.

8. Nocera M, Shanahan M, Murphy RA, Sullivan KM, Barr M, et al. (2016) A state wide nurse training program for a hospital based infant abusive head trauma prevention program in Practice 16(1). e1-e6.

9. Reese LS, Heiden EO, Kim KQ, Yang J (2014) Evaluation of period of PURPLE crying, an abusive head trauma prevention program. Journal of Obstetric, Gynecologic \& Neonatal Nursing 43(6): 752-761.
10. Barr RG, Trent RB, Cross J. (2006) Age-related incidence curve of hospitalized Shaken Baby Syndrome cases: convergent evidence for crying as a trigger to shaking. Child Abuse Neglect 30(1): 7-16.

11. Reijneveld SA, van der Wal MF, Brugman E, HiraSing RA, VerlooveVanhorick SP (2004) Prevalence of parental behavior to diminish the crying of infants that may lead to abuse. Ned Tijdschr Geneeskd 148(45): 2227-2230.

12. Allen K (2014) The Neonatal Nurse's role in preventing abusive head trauma. Advances in Neonatal Care 14(5): 336-342.

13. Zolotor AJ, Runyan DK, Shanahan M, Durrance CP, Nocera M, et al. (2015) Effectiveness of a state wide abusive head trauma prevention program in North Carolina. JAMA Pediatrics 169(12): 1126-1131.

14. Scaife ER, Statler KD (2010) Traumatic brain injury: preferred methods and targets for resuscitation. Current Opinion in Pediatrics 22(3): 339345 .

15. Walker PA, Harting MT, Baumgartner JE, Fletcher S, Strobel N, et al. (2009) Modern Approaches to Pediatric Brain Injury Therapy J Trauma 67(2 Suppl): 120-127.

16. Abelson Mitchell N (2008) Epidemiology and prevention of head injuries: literature review. Journal of Clinical Nursing 17(1): 46-57.

17. Mirzai H, Yağlı N, Tekin İ (2005) Epidemiological and clinical features of head injury patients who applied to Celal Bayar University Medical Faculty Emergency Department. Turkish Journal of Trauma Emergency Surgery 11(2): 146-52.

18. Söylet Y, Emir H (2006) Pediatric Trauma. Interior: Taviloğlu K, et al. [Eds.] Trauma and Resuscitation Course, Logos Publishing. pp. 171- 187.

19. Atilla F, Bayır H (2008) Severe Head Trauma in Infants and Children. Interior: Karaböcüoğlu M, et al. [Eds.]. Child and Intensive Care. 1st ed. Istanbul Medical Publishing. pp. 929-947

20. Kuğuoğlu S (2008). Pediatric Trauma. Interior: Şelimen D, et al. [Eds.] Trauma and Resuscitation Course Book for Nurses, Technicians and Technicians, Kuban Matbaacılık. pp. 177- 192.

21. Savaș A (2005) Indications for emergency surgery in head injuries. Ertekin C, et al. [Eds.]. Trauma. 1st editor, Istanbul: Istanbul Medical Publishing. pp. 647-653.

22. Algıer L, Abbasoğlu A, Pınar G, Şahin Z, Temurlenk H, et al. (2004) Nursing interventions in patients with trauma. Journal of Atatürk University School of Nursing 7(2): 59-65.

23. Öztekin D, Uğraș AG (2009) Nursing interventions in patients suffering from head trauma. Firat Health Services Magazine 4(11): 145- 157.

24. Bennett TD, Marsh R, Maertens JA, Rutebemberwa A, Morris MA, et al. (2019) Decision-making about intracranial pressure monitor placement in children with traumatic brain injury. Pediatric Critical Care Medicine 20(7): 645-651.

25. Eti Aslan F (204) Head Traumas. Inner: Şelimen D [Ed]. Urgent Care. Extended $3^{\text {rd }}$ editor. Tavaslı Printing House, pp. 231-259

26. Kochanek PM, Carney N, Adelson PD, Ashwal S, Bell MJ, et al. (2012) Guidelines for the acute medical management of severe traumatic brain injury in infants, children, and adolescents. Chapter 11. Use of Hyperosmolar Therapy in the Management of Severe Pediatric Traumatic Brain Injury. Pediatric critical care medicine: a journal of the Society of Critical Care Medicine and the World Federation of Pediatric Intensive and Critical Care Societies 4(3): S40-S44. 